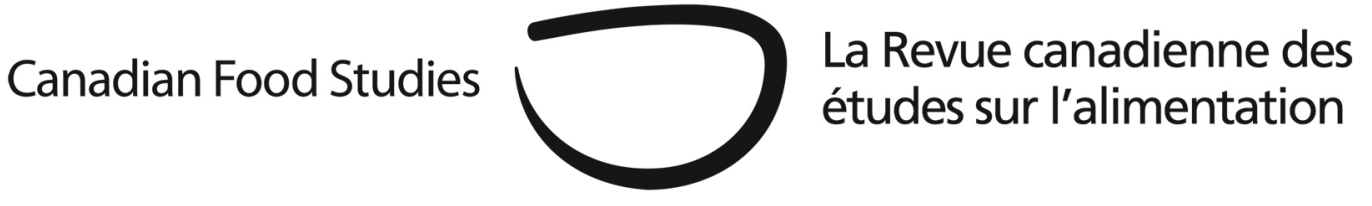

Original Research Article

\title{
Local food, farmland, and urban development: A case of land grabbing North American style
}

\author{
Elizabeth Ann Smythe \\ Concordia University of Edmonton, elizabeth.smythe@concordia.ab.ca
}

\begin{abstract}
This article examines emerging forms of investment and land speculation and their implications for local food movements in urban areas. These investments involve purchases of large tracts of land in growing urban areas with a view to profiting from re-zoning and exiting the market well before development occurs. It uses a case study in northeast Edmonton, Alberta that concerns the struggle for an urban food and agriculture strategy as well as the protection of prime foodproducing land from urban development. The article shows how local food activists were able to mobilize citizens in support of local food and preservation of land, and were able to initiate a process linking land-use decisions to a food and agriculture strategy. However, the power of development interests and the planning process itself resulted in a strategy that was weak on preserving land for food, and a land development plan that preserves little land and threatens the future of existing food producers in the area. The article argues that new forms of "land grabbing" in North America pose challenges to movements seeking to preserve local food production.

Keywords: land grabbing, local food, urban development, speculation, investment, North America, Edmonton
\end{abstract}




\section{Introduction}

The term "land grabbing" has been widely used to describe the acquisition of large tracts of land in the global South by foreign interests in the wake of the global food crisis of 2007-08. As Borras and Franco (2012) indicate, enclosures and dispossession were the direct result of "land speculation in recent years mainly, but not solely, around the large-scale production and export of food and biofuels" (p. 35). However the phrase "land grabbing" is equally apt for speculation that drives changes in land use, which have many faces and may be occurring not just in the global South.

Movements have also emerged in the global South and North that focus on food security, food sovereignty, and the development of alternative, more localized food systems. Yet few studies have linked the two processes and examined how new forms of global investment in land affect attempts to build and preserve local food systems via the protection of urban and periurban agricultural land. This article uses a case study of a local food movement in a Canadian city to show how speculative investments in land for development - which can be seen as a form of land grabbing - have increased the challenges of building a local food system, despite the growing public concern about food security and access to local food.

Many scholars associate land grabbing with advanced capitalism and greater cross-border flows of capital engaged in financial speculation (Margulis, McKeon \& Borras, 2013). This trend to financialization, driven by private equity firms, affects all aspects of the food system, as Burch and Lawrence (2013) point out. Borras and Franco (2012) note that in the global South, land grabbing involves changes in land use from local food production to intensive production for export markets. However, financial speculation can precipitate an array of uses for the land, depending on which is most likely to provide strong returns on investment. In some cases land may be leased back to growers and used for intensive export crop production, betting on stronger future commodity prices. Alternatively, it could be taken out of agricultural production altogether. For peasants in the global South who may lack access to land and face trade rules that sanction commodity food dumping, this is one more threat to food producer livelihoods. Land grabbing may also have goals that go beyond a simple maximization of returns for investors-taking the form of "agro-security mercantilism," where state actors and their agents "commandeer offshore lands for supplies of food, feed and fuel” (McMichael, 2013, p. 47). But as Margulis and Porter (2013) point out, the transnational nature of land grabbing belies traditional core-periphery or North-South dynamics. For example, Indonesia has attempted to buy large tracts of grazing land in Australia to raise beef to supply its home market (ABS News, 2013).

Borras et al. (2012) make a case for questioning some of the prevailing assumptions about how land grabbing is defined and where it is occurring, suggesting that too strict and narrow a definition may lead analysts to miss important trends that have implications for agrarian change and food security. They suggest that there are three key features of this type of investment. First it is "control grabbing," that is, creating the "power to control land" and "deriv(ing) benefit from such control” (Borras et al., 2012, p. 404). A second key feature is the 
relatively large scale of such land grabs; and third, they argue that this process takes place "within the dynamics of capital accumulation strategies responding to the convergence of multiple crises: food, energy/fuel, climate change and financial crisis (where finance capital started to look for new and safer investment opportunities)” (Borras et al., 2012, p. 404).

On that basis, we can argue that many large-scale land acquisitions across the globe fit these criteria, as part of large investment companies, pension funds, and sovereign wealth funds. Those concerned about preserving farmland in North America are starting to make these links, and to acknowledge the need to recognize different forms of investment and their implications for food systems - as reflected in "Land for Food: A Focus on Farmland Protection and Land Grabbing” (Vol. 4 Issue 1), a special issue of the Journal of Agriculture, Food Systems, and Community Development. Some claim that the trend toward large-scale land purchases by global firms is happening in North America as well. As the Canadian National Farmers' Union (NFU) points out:

In many parts of Canada land is being purchased by absentee investors through speculative land investment corporations, and then rented back to farmers or operated with hired labour, including temporary migrant workers. The farmland investors are not interested in food production, but in a revenue stream, and thus make cropping decisions based on profitability rather than land stewardship. (National Farmers’ Union, 2010, p. 9)

Large-scale purchases of agricultural land in North America may be undertaken to vertically integrate and control all aspects of the value chain ("control grabbing”). It can also be done, as is the case of many investment funds, as a speculative venture focused on a high rate of return, based on increasing land value or the future value of crops it may produce. Such investment began before the 2008 food crisis, but that crisis increased investors' awareness of North American investment opportunities since much agricultural land is deemed to be relatively undervalued (Sommerville, 2013). Sommerville notes the trend toward this type of investment in Saskatchewan through farmland investment funds (FIFs), where profits are derived from a variety of sources, including leasing the land to farmers, appreciation of farmland values, and other tax benefits. The NFU report notes another way in which investors can speculate: by identifying agricultural land in areas adjacent to major cities where anticipated high rates of population or industrial growth are likely to occur. While property speculation is not new, these investment companies pool large amounts of capital, purchase agricultural land, and hold it until it is converted to use for residential and commercial development. This process, given differences in land values, can be highly lucrative.

Although not driven directly by high food prices, as are some of the investments outlined above, I argue (along the lines of Borras et al., 2012) that the growth, scale, and impact of this type of investment is new, is linked to financialization, and has implications for food production. Like land grabbing in the global South, it increases the scale of the loss of food productionparticularly near urban areas_-by removing land from production and driving up the price of 
remaining farmland beyond what local producers can afford. This has implications for those seeking to preserve or develop local food systems. This article examines the challenges of resisting the conversion of food land within an urban area to residential and commercial uses, in the face of the growth in this type of investment. I contend that if preserving agricultural land for local food production is a key part of developing a local and alternative food system — even where there is strong public support for land preservation — this trend may make such efforts increasingly problematic.

This case study illustrates how growing concerns about the provenance of food mobilized the public and resulted in a commitment of elected officials to develop a food strategy. However, the power of an international investment firm engaged in property speculation on agricultural land within the city limits, and allied with local property developers, was able to partially undermine the Council's commitment to addressing local food issues. Despite citizens' strongly expressed desire to preserve a portion of this prime land for food production, the local food movement was unable to stop a development plan that would preserve little of this land beyond that owned by a small group of farmers. Moreover, these farmers now fear that further encroachment of residential and commercial development will ultimately threaten their operations.

Local food movements have been the subject of much study. Some question whether they are even social movements (Starr, 2010) given that they are largely urban-based and involve everyone from restaurateurs to public health officials, environmental and social justice activists, community gardeners, and farmers. Others criticize movements for ignoring justice issues (Allen, 2010) and focusing on using consumer choice and public procurement to support a local and sustainably produced food supply. They question the transformative capacity of such approaches (DeLind, 2011; Guthman, 2007), asserting that movements must confront the powerful to change the food system-including, I would suggest, at the local level where landuse decisions are made.

Many local food movements have lacked the capacity to take on such issues or, in some cases, faced a situation in which much of the adjacent food-producing land had already been lost to urban development. For North American cities where urban growth and property development have been the basis of much local wealth creation, food movements trying to preserve farmland and challenge city land-use decisions are taking on issues at the very core of local politics. However given the pace of loss of some of the best food-growing farmland in peri-urban areas (Alberta Agriculture, 2002) and the emergence of global investors now focused on using these remaining lands for financial speculation, it is important to examine cases in which food movements have engaged on these issues, and to assess what lessons they provide.

\section{Methodology}

This article uses a qualitative case study of the 2008-13 local food campaign to save arable land in the city of Edmonton, Alberta, to examine this type of investment and its impact on building a 
local food system. The author participated in the local food movement through membership in a local organization, the Greater Edmonton Alliance (GEA), and was also a participant observer in community meetings and at GEA meetings with city councillors and one developer. The author also attended and spoke at public hearings at Edmonton City Hall. These participant observations were supplemented by retrospective interviews with two co-chairs of GEA's local food team who sat on advisory and stakeholder committees described below. In addition, the author reviewed minutes of all meetings of the GEA local food team and all relevant documents, surveys and studies commissioned by the City of Edmonton as part of the development of a food strategy. Documents provided by the city and the developer leading the planning process for the Area Structure Plan for Northeast Edmonton were reviewed, as well as media articles and blogs from reputable observers of local urban politics. The article begins with a brief discussion of the context in which this issue emerged.

\section{The context: Investment in land on the prairies}

While western Canadian agriculture has followed the industrial model of North America in both intensive livestock and crop production, family farms have remained the unit of production - but have grown in size and decreased in number. According to Statistics Canada, since 1991 the average farm size in Canada increased from 598 to 778 acres, while the number of farm operators decreased from 390,875 to 293,925-a 24.8\% drop (Beaulieu, 2014). The average age of farmers also continues to increase, with more than half over fifty-five years old.

As Magnan notes, middle-sized farms in western Canada have largely disappeared. Though some small-scale farms remain, many of the operators of the largest farms are best described as farm entrepreneurs (Magnan, 2012). While non-family corporate farms remain rare, investors have begun to pay attention to agricultural land. Sommerville (2013) outlines the demand drivers that are attracting such investors and the factors that lead to a supply of farmland for sale. The latter include the inability to make a living because of declining farm incomes, debt, aging, succession, the need to finance retirement, and urban encroachment—such as roads or services bisecting previously contiguous land.

The NFU has documented the activities of investment companies such as Hancock Agricultural Investment Group (HAIG) in the US, which oversees "approximately \$1.2 billion worth of agricultural real estate for institutional investors” (NFU, 2010, p. 12). The largest farmland investment management company in Canada, Assiniboia Capital Corp., manages almost 100,000 acres (NFU, 2010, p. 10). Sommerville (2013) notes two other FIFs that have been investing in Saskatchewan since 2005 (AgCapita Farmland Investment Partnerships and Bonnefield Financial). The NFU report indicates a second type of investment funds, focused on speculating using agricultural land. Such land is often leased back to farmers at low rates, while being held until zoning changes. Commodity crops, which require no long-term investment, are 
then grown until the land is re-zoned. One such company that has been rapidly expanding its investor base and buying up land is Walton International.

Founded as a real estate company by Patrick and Maureen Doherty in 1979 in Calgary, Walton rapidly expanded into investment when it began soliciting funds and opening offices outside Canada in Hong Kong, Singapore, Malaysia, and finally Europe in 2005. The company focuses on its expertise in analysis of the North American land market, noting on its European office website that "the size of Canada and the USA allow their cities to grow horizontally" (Walton International, 2014c). It gathers key data on various areas across North America, identifies growth opportunities for its investors, and then strategically acquires land in those regions.

The company's expansion into land banking investment after 2000, through its Asian offices, marked a turning point in its growth trajectory (Walton International, 2014b). While the company portrays itself to local authorities and the community both as a land banker and developer, investor information previously available on their websites (e.g., Walton International, 2005) indicates that Walton buys and holds land—on average for seven years—in peripheral urban areas, to profit when the land is re-zoned or developed. Describing itself as "one of North America's premier land asset managers" (Walton International, 2014a), it markets products to investors - many in Asia — based on a formula of careful planning, purchasing, developing and exiting projects, and distributing proceeds. A history of the company on its European office website describes how its "strategic conquest of the real estate market in Edmonton began in 2001" (Walton International, 2014b). Very soon the land under Walton management had "quadrupled to 16,000 acres in Alberta alone” (Walton International, 2014b), most of it in new areas slated for future development around Calgary and Edmonton. These areas were experiencing growth pressures, particularly in the 2003-07 period, when oil prices were high and the Alberta economy was booming. Identifying the sub-prime mortgage crisis in the United States as an investment opportunity, the company has been expanding acquisitions in the US as well in recent years.

Walton also identified market opportunities with the creation of the Ontario Greenbelt in 2005 and specifically targeted areas just outside it. Its acquisition of many farms in 2006-07 in Brant County, Ontario, a food-growing area, raised local controversy. The intent of the land purchases, according to media articles in the fall of 2007, was to change "the scope of urban growth beyond already-established boundaries to take in their newly acquired acreage" (Michael, 2007). The key to such influence, as Walton's own promotional material indicates, is to become the dominant land owner in the area (control grabbing). With such distant and dispersed investor owners, as Haley notes, there is little connection between the local community and the purchasers of this land. "These shareholders may have no idea of what they are investing in and how it affects the community where the investment physically exists. One small farm may have hundreds of shareholders" (Haley, 2013).

A similar pattern has emerged in Edmonton. According to its most recent report Walton has more than 88,000 acres of land under administration, with assets valued at over $\$ 4.3$ billion 
CAD, and with over 90,000 investors worldwide. Walton manages approximately 6,000 acres in and around the City of Calgary and approximately 9,000 acres within the City of Edmonton. Walton views the "retail end" of the real estate life cycle — that is, building or redeveloping property - as "competitive and can be subject to volatility, due to fluctuations in costs and interest rates” (Walton International, 2005). The secret to maximizing Walton’s return for investors is in timing its exit from the market at the project planning stage, when the land in question has been rezoned.

\section{The context: Edmonton, Alberta}

Edmonton has grown by 11.2 percent in the past five years (City of Edmonton, 2012c) and, with adjacent communities, the region's population is over one million. In a province of just under four million people, it is also the seat of Alberta's provincial government. Alberta's history is one of the displacement of the native population, immigration, and the development of agriculture as the main economic focus-until the discovery of oil in the 1940s and the development of a petro-economy, subject to the boom and bust cycles of commodity prices. Alberta accounts for 62.8 percent of Canada's primary energy production, mostly fossil fuels (Natural Resources Canada, 2013). Strong energy-related growth has led to significant inmigration to the province in the past decade. Many of the sites of oil production, especially of the oil/tar sands, and the attendant service industries, are located north of Edmonton. Politically, the Progressive Conservative Party has dominated Alberta for over four decades.

The city of Edmonton is divided into twelve wards, with councillors elected for threeyear terms along with a directly elected mayor. Candidates run on a non-partisan basis. Much of the city's post-World War II population growth has been accommodated via annexations of land from neighboring counties in a process governed by provincial legislation. A bitter annexation battle occurred in 1982 when the city annexed 37,000 hectares-much of it agricultural land to the east and north — with a view to eventual development as the city grew (Masson and Lesage 1994). Many of those residents in the northeast who were incorporated into the city faced both poor services - relative to other areas of the city-and major property tax increases, a legacy that relates to our case study.

In the 1990s, a group seeking to counter provincial government policies of retrenchment decided to form a broad-based community organization in Edmonton. It was modeled on the Industrial Areas Foundation in the United States, which had its roots in the work of social activist Saul Alinsky (Lange, 2013). The organization developed out of ten years of meetings, discussions, and relationship building at the local level, culminating in the 2005 founding convention of the Greater Edmonton Alliance (GEA). GEA's vision as described on its website is to create:

An Edmonton where all citizens: participate effectively in the public decisionmaking process, engage in informed, thoughtful and relevant dialogue and action 
around issues and concerns that shape their lives, have the power to negotiate positive social transformation and hold government and market sector leaders accountable to the citizenry (Greater Edmonton Alliance, 2013, np).

The method to achieve this vision is one that:

seeks out and develops leaders, builds power by developing public, accountable relationships with and between individuals, institutions, networks and decision makers, listens across its membership to identify issues of common concern, researches common issues to discover opportunities for action, takes disciplined, organized action to build resilient institutions and communities and a more just and equitable Greater Edmonton Region and engages in ongoing evaluation and reflection (Greater Edmonton Alliance, 2013, np).

GEA is organized around over twenty local institutions that are dues-paying members, including many churches, some unions, and community organizations.

Its first major campaign in 2006 and 2007 addressed the re-development of older rental complexes in two low-income residential neighborhoods that were slated to be turned into highpriced condominiums, reflecting the economic boom and rapidly increasing real estate prices. By mobilizing tenants and the local community, building relationships, and demonstrating its power, GEA was able to get to the table with local developers, the city, and non-profit groups. It then engaged in negotiations with the other parties to increase the number of affordable housing units that would be provided in the project. Since the focus of the campaign was very specific - and the "ask" of developers fairly modest-GEA was able to claim a success for the community. Policy tools such as tax and other incentives provided acceptable trade-offs for developers. That experience perhaps led GEA activists to expect a similar process would unfold in dealing with the city council and developer interests on other issues. In 2008, GEA activists turned their attention to food.

The focus on GEA's role in the food campaign is not meant to suggest that there was no local food activism in Edmonton prior to 2008. In fact many groups were concerned about foodrelated issues such as community gardens, farmers' markets, environmental sustainability, and urban sprawl. However these did not constitute a focused or politicized food movement.

\section{Waking up to food security and locally produced food}

The 2008 year constituted a wake-up call for many, as global food prices soared, resulting in increasing food insecurity, food riots in a number of countries, and growing attention in the national and local media in Canada to food issues. Global food prices fell then rose again in following years, reflecting continuing and increasing volatility in food pricing-likely to worsen with climate change and the growing international financial speculation in food stocks (Food and Agricultural Organization, 2012; Clapp, 2009). 
In Edmonton, concerns about food insecurity and the provenance of food were reflected in a number of ways. For example, in 2008, ten community activists gathered at a local Edmonton church (one of GEA's member institutions) to listen to one another's concerns about pressures facing their families, and to ask questions about their food. In April 2008, the group hosted a local food dinner inviting GEA members, other local food activists, and several farmers. For GEA, involvement represented the possibility of taking on another local issue to which they could bring together a number of groups that were "not connected" and provide the organization and "local food advocacy piece that was missing" (Interview 2013).

At subsequent dinners, activists met a group of food-producing farmers, some of whom expressed concerns about the threat to prime agricultural land within the city limits from development. In September 2008, GEA launched its "Shake the Hand that Feeds You" campaign. It was intended to demonstrate public support for local food producers, raise awareness about local food, and show the potential consumer demand for local food, by organizing the purchase of 300 food baskets from local farmers. The "This Land is Our Land" campaign followed shortly thereafter and began addressing land-use questions. GEA's goal was to influence the nature of the city's ten-year land-use plan—called the Municipal Development Plan (City of Edmonton, 2012b) - to ensure that, when making development decisions, Council would be required to take into account any impact their decision might have on food security and the local food system. Of particular concern to GEA were decisions that might lead to the loss of farmland and local food producers. This focus led GEA into the civic arena, where it would be challenging the key interests and actors influencing city land-use decisions. This became clearer as activists began to meet with councillors in the fall of 2008 to talk about the future sources of the city's food. Efforts to engage key decision makers such as the mayor, the city's chief planner, and the CEO of Walton proved difficult. Assuming these actors saw no reason to meet with GEA, GEA activists concluded that they needed to demonstrate power in order to get to the negotiating table.

Operating from the principle that the power of organized money can only be countered by the power of organized and mobilized citizens, and drawing on its disciplined and organized membership structure, GEA was able to bring over 500 citizens in November 2008 to the city council chambers at the first public hearing of the City's Municipal Development Plan (City of Edmonton, 2012b). It got the attention of both the local media and council, which directed its administration to gather information on a food security strategy and on issues around agricultural lands. However, this did not ensure that any subsequent Council decisions and plans would take those concerns into account. Thus, GEA began meeting with, and trying to influence, planners, councillors, and non-farming land owners in areas of potential development. GEA also laid out a vision for a vibrant and sustainable local food system in a report, The Way We Eat, which was presented to council in the spring of 2009 (Greater Edmonton Alliance, 2009).

While using a frame of food security, the vision was a holistic one that linked a local food system to improving health, and building community and prosperity for current and future generations. They argued that food should be a central pillar of planning the city's future. They 
asked that the city " integrate local food system impact, including productive capacity, carrying capacity, economic linkages and sustainability, into all decisions regarding the conversion of agricultural lands to other uses” (GEA, 2009). However, as Beckie et al. (2013) point out, the responsibility to protect farmland had been shifted from the province to municipalities in the 1990s. Given growth pressures from resource development and the investor-driven land purchases described above, this struggle would be very different from GEA's earlier experience with the city over low-cost housing. The struggle over a local food system would be at the city council level and would have to counter very powerful economic interests within the prevailing frames of growth and individual property rights that underpin the dynamics of landuse decisions.

On November 21, 2009, using its capacity to organize and mobilize, GEA brought another 500 people to the second MDP public hearing. A key motion at the hearing was proposed by a sympathetic councillor and passed. This motion authorized the beginning of planning for the areas slated for urban growth, but required that future development decisions take into account a yet-to-be-developed city-wide food and agriculture strategy. This amendment tied the future development of agricultural lands to the completion of, and compliance with, a food strategy: a "win” from GEA's perspective. However, the councillor in Ward 3 (Northeast Edmonton), Tony Caterina, supported by the mayor, moved a further amendment to delete the food strategy from the list above, which was barely defeated in a seven-to-six vote. This indicated that, on matters of development and land-use council votes, even those initially supporting GEA and the idea of a food strategy could not be taken for granted-likely because opposition to GEA's efforts had begun to mobilize. The final passage of the motion also meant that, while there was now a requirement that any food strategy developed by the city be taken into account in decision making, such a strategy would need to have clear and timely recommendations on a local food system that could inform council's land development decisions. What the food and agriculture strategy said about food-producing lands in the northeast would be crucial in guiding the area's development.

\section{Food, land use and development—no skin in the game}

The planning and approval processes for development and land-use decisions in Edmonton reflect assumptions about the role of citizens in the process. The drafting of a proposed development plan for any area of the city is led by key economic and other interests involved in, or affected by the project. If there is a majority landowner in the area, they pay for and lead the development of the draft plan. Other stakeholders, for example property owners—both residential and commercial— who would be directly affected by the proposed development or zoning changes, would be consulted along with relevant city planners. However, the broader public, which might have a longer-term interest in the cumulative impact of the development on the city, do not have a right to be consulted. 
In the case of the northeast, the majority landowners were not food producers, but rather developers and land investors, the largest of which was Walton. When the land in the northeast became part of Edmonton in the early 1980s, it was on the assumption that it would stay in agricultural production until required to meet urban growth needs, both residential and commercial. The need for such development was linked to the planned future development of an Edmonton Energy and Technology Park tied to the petroleum sector. Walton is also the primary developer and land owner in the industrial park. Walton's acquisition of land in the northeast, much of it agricultural, put it in a position of leading the draft plan. Once approved, the plan could lead to re-zoning that would yield substantial returns to its investors long before actual development occurred.

The 1982 annexation had led to some increases in land prices in the northeast, which were not sustained as a result of economic downturns. A number of farmers in the region continued to farm and a small number expanded, selling into the growing number of markets in the city and the region. Some became increasingly concerned and voiced fears that further residential and commercial development would encroach on their operations and threaten their future (Stolte, 2011). As a consultant's report prepared as part of the development of a food strategy indicates, the land in their area has some of the most fertile (class one) soil in Alberta and in all of Canada, near the North Saskatchewan River (HB Lanarc Consultants, 2012). The sandy soil allows for an early start on the very short season for growing root crops. However other non-farming landowners in the area felt they had unfairly borne the cost of annexation of the region to the city, and viewed potential development positively—hoping it would bring better services to their neighborhoods or help them to sell their land at a profit to developers.

Those owning land or affected directly by changes to the zoning are by definition those with interests, and therefore, a claim to be consulted in the decision-making process. The notion that the future of lands growing food within the city boundaries might somehow relate to a broader public interest in a resilient and more secure food system was foreign to many councillors.

\section{Round One: Food and agriculture strategy—consultation or cooptation?}

These decisions of Council in 2009 set two formal processes in motion. The first called for the development and approval of a citywide food strategy, and the second for a process to develop the draft Area Structure Plan for the northeast (traditionally called the Horse Hill area), as Figure 1 indicates.

Each process involved an advisory committee. GEA representatives participated in both these parallel processes. However the structure and procedures of consultation for each differed. The food strategy involved broad public consultation beyond the advisory committee, involving a food conference in 2012, and a series of public consultations - which included surveys, a citizens' panel, and public feedback on the initial draft of the strategy. These broader consultations and the citizen engagement process are discussed in Beckie et al. (2013), and 
described on the City of Edmonton website (http://www.edmonton.ca/city_government/ urban_planning_and_design/food-and-urban-agriculture.aspx). The focus here is on the committee processes and the broader political struggle to influence Council.

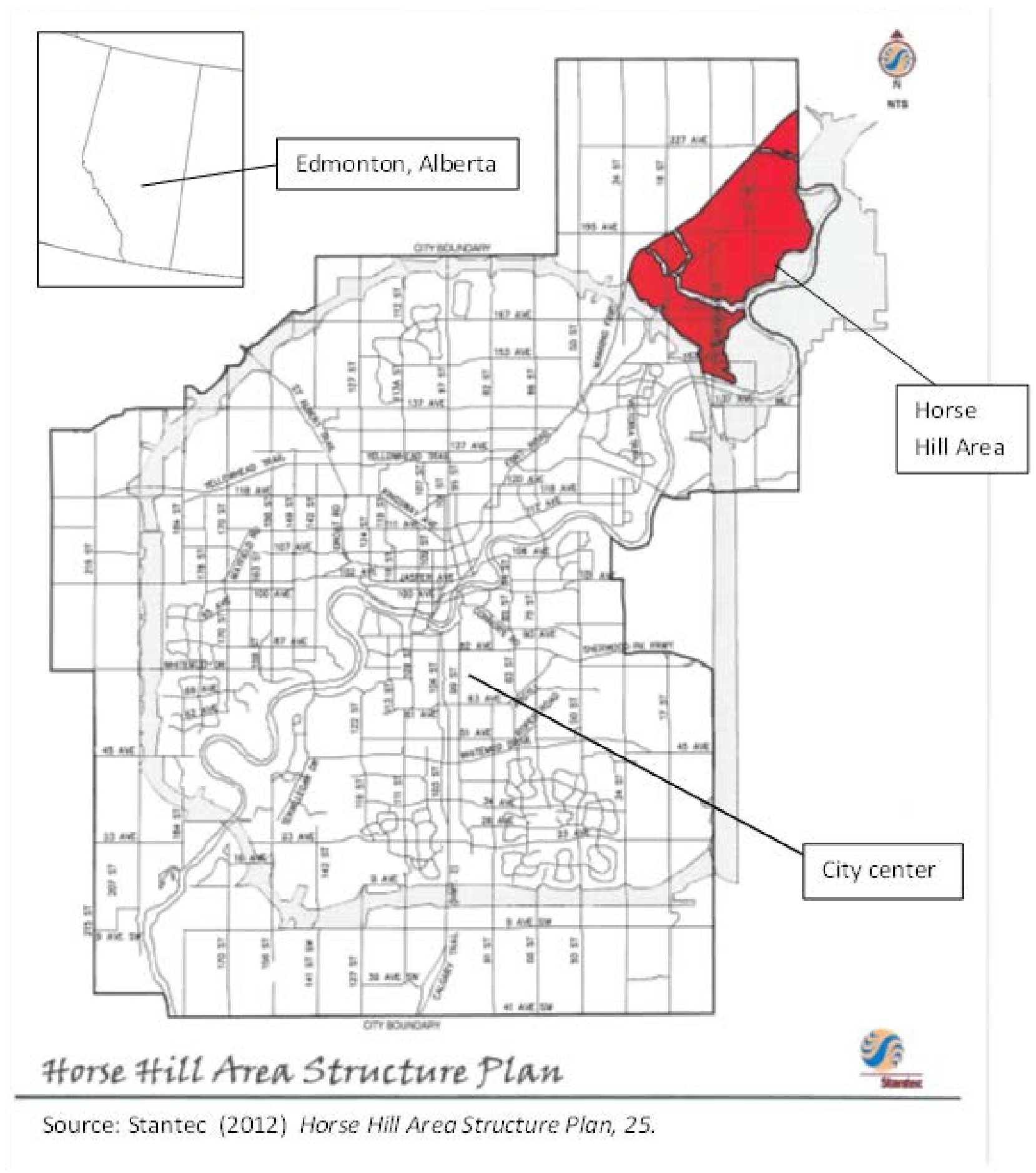

Figure 1: Location plan showing the Horse Hill area (City of Edmonton, 2013) 
The fourteen-member advisory committee on the food strategy included a wide array of organizations and individuals active on food issues, but the process of appointment was less than transparent. It included three developers and a Dutch trade office representative, who were there at the invitation of the mayor. The short timelines, both for the work of the committee and for the broader public consultations, seemed rushed (Interview 2013). For example, the release of the first draft of the food strategy on October 1, 2012 had a deadline for public feedback of October 8 , inclusive of the Thanksgiving holiday. At the advisory committee, the presence of developers meant that a deadlock developed early over land use, which took those issues off the tabledespite public feedback overwhelmingly supportive of preserving land for food. The GEA representative raised the question of whether the process was set up to fail to give clear guidance on land use issues (Interview 2013). For GEA the process was frustrating. It raised the risk that, having agreed to engage in a consultation process to address land use, which was now being controlled by those who did not want it, GEA would end up being forced to criticize or reject the resulting food strategy for which it had lobbied so hard.

In contrast to the food strategy, the parallel development of the Area Structure Plan involved a twenty-one-member advisory committee dominated by developers (nine) and property owners in the northeast (seven). The plan was prepared by consultant Stantec (hired by, and working on behalf of, Walton, the largest property owner) and three other developers. While the committee included a few food growers in the northeast (three), and two GEA representatives, they were very much in the minority. What GEA did not have was a direct interest or stake in the plan. As the councillor representing the northeast, Tony Caterina, said,

If you own the land and you want to grow berries, go ahead. If you don't own the land, I would say the same thing, get the heck out of the way. You have no interest. We're going to have everybody with no interest, financially or otherwise, coming forward supporting something that they really have no skin in the game about, and those that do, are going to suffer the consequences (Male, 2012).

For Caterina, "no skin in the game” meant no right to have a voice. Despite the high level of citizen support for, and concern about, retaining local food production, the key decision-making processes were driven by development interests and largely out of public sight. The only public processes available were the ones related to the development of the food strategy.

GEA's support of food growers in the northeast led to a formal link when the food producers formed the Northeast Edmonton Agricultural Producers (NEAP), and became a GEA member in October 2010. Recognizing that momentum on Council was with the Area Structure Plan and the developers, and that the food and agriculture strategy was stalemated, GEA took a risk and moved off its initial message — that the city's food and agriculture strategy should mandate or provide good information before decisions were made on the future of foodproducing lands in the northeast. Instead, GEA developed a formal "ask” of Council to preserve a portion of land in the northeast for food production. This move brought GEA into a realm that 
directly challenged powerful economic actors and threatened to subvert the dominant growth and property rights frames (Claeys, 2012).

Developed after consultations with the food producers and others, GEA saw the ask as modest, given that Edmonton had lost three-quarters of its agricultural land since 2006. GEA asked that 600 hectares of contiguous land in the northeast, an area south and east of the railroad, be preserved for agriculture in perpetuity. The 600 hectares represented ten percent of the agricultural land in the city and less than a third of the area of the Northeast plan, but it has the richest, most productive soil on land near the river. However, as the city administration pointed out in its report to Council on the food strategy, the city had never turned down a development in order to preserve agricultural land.

A cost-benefit analysis of preserving this land was missing from the food strategy. Several councillors made it clear that, since a cost-benefit analysis was the only basis on which preservation could be justified, it would drive their decision, and the onus was on GEA to make a "business case.” Making a purely economic case for agriculture is a hard task for a volunteer organization and, as one activist commented, one not required of many proponents of major projects.

GEA's ask to preserve farmland put the issue of land rezoning front and center before Council and in the public eye. In hindsight it was deeply polarizing (Interview 2013), and mobilized developers and other opponents-including the non-farming property owners in the northeast who formed themselves into the Northeast Edmonton Alliance (NEEA). Working with the local community association, the Horse Hill Community League, and developers, NEEA made its opposition to GEA's ask loud and clear. They also criticized the food growers in the northeast who had sold off parcels of land in the process. ${ }^{1}$ The debate in the media and at Council quickly turned to the land question alone, and the broader vision for a local food system was lost. The struggle over the Food Strategy now focused heavily on what it did or did not say about land use. GEA became increasingly shut out, as councillors refused to meet with GEA until the food strategy was released publicly, even though it was clear a draft Area Structure Plan was already circulating behind the scenes.

The proposal to preserve farmland that GEA and its allies had put forward challenged powerful frames of property rights, growth, and development that dominate land-use issues in the urban political arena. Land grabbing of the kind described above relies on a scale of land acquisition that affords the owners much control of the land-use planning and decision process, putting these investors and their developer allies at the centre of the table. Those advocating preservation of farmland were no longer at the table. The challenge for local food activists was one of framing the land-use issue in terms of a local sustainable food system-which could be seen as a "common good" in opposition to the dominant property rights and urban growth frames. That struggle is discussed below.

\footnotetext{
${ }^{1}$ A number of farmers—in an effort to consolidate their holdings, or to split up a family holding —-had sold off some of their land to developers, providing NEEA with the opportunity to label them hypocrites who had profited from the prospect of development while denying it to others.
} 


\section{Framing the issue of local food}

In the struggle over local food, actors employed a number of frames, countered competing frames and narratives, and sometimes shifted frames. The initial GEA campaign in 2008 used a frame of food security and the need for a resilient local food system that could, in the words of the city's strategic environmental plan, "have the capacity to withstand and bounce back intact from environmental (or other) disturbances” (City of Edmonton, 2011, p. 2). The frame focused on environmental sustainability, rapidly rising and volatile food prices, and public concerns about the provenance and quality of food. Such a frame was never going to be enough to persuade Council to take action, when councillors are driven largely by shorter-term concerns around service delivery, infrastructure, growth, and development. A second GEA frame focused on the benefits to the economy of a local food system, emphasizing the spinoffs for local business and food production. In this case, restaurateurs and others involved in organizations like Live Local played a role in emphasizing the economic benefits from local production. This was picked up in GEA's The Way We Eat.

Councillors, developers and others who fought the local food movement's goals employed two very powerful frames. The first is the "growth" frame that speaks of the need for more single-family housing to deal with increased population forecasts and housing demand; development of city lands to avoid leapfrog development outside the city boundaries; and development to accommodate growth connected to, and spinning off from, energy resource development-much of which was forecast to occur in the northeast. A fiscal corollary to the growth frame claims that growth is vital to maintain the urban property tax base and ease the burden on taxpayers. This frame was less persuasive, given that new suburban developments, while seeming to provide initial revenues to the city, cost more in the longer term for maintenance of services and infrastructure. GEA could show that productive agricultural land, while bringing in less tax revenue in the short term, needs little servicing and is of net benefit to city revenues in the long term.

The second frame used by GEA’s opponents was the potent property rights frame, and the argument that such rights trump any notion of the public or common good. This frame is behind the "skin in the game" comments of Councillor Caterina and the landowner-led planning process. It suggests that only those who own land ought to have a voice in how it is used, a claim that resonates widely, despite being denied by both common law and the concept of zoning. Opponents of preserving land, such as the NEEA, used this frame effectively. Some councillors, as a result, claimed that the only way to forestall development of food land was to buy the land in question at the highest market value, despite the many policy tools that local food advocates pointed out were available to conserve such land. ${ }^{2}$ The mayor, himself a former property developer, championed the property rights frame. The claim was also made that food producers owning agricultural land were free to continue farming it no matter what happens to adjacent

\footnotetext{
${ }^{2}$ GEA even went as far as to sponsor a workshop on some of these tools, including easements, land swaps, development transfer credits, and land trusts. Few developers or city officials attended.
} 
property, a claim clearly challenged by many studies of urban encroachment and development (Sokolow et al., 2010).

As the draft food strategy's weak recommendations on land use became clear, despite strong public support for preserving agricultural land, GEA and other commentators-including the local newspaper the Edmonton Journal-raised the issue of democracy (Edmonton Journal, 2012). The issue was no longer just about preserving agricultural land, but rather whose voice is heard at city hall, and how democratic and accountable the system really is. That this had struck a note with many was made evident by citizens filling the main chamber of city hall and two overflow rooms to capacity on October 26, 2012, despite these hearings being held in the middle of a workday.

Many local food activists involved in the food strategy consultations, along with other community groups, refused to sign off on the draft strategy, and appeared at the public hearings to criticize it. GEA opposed the strategy's weak and non-committal language that lacked specific and firm commitments to any actions beyond establishing a food council. They argued it provided no clear direction about the information needed to make future decisions on land, and offered a vague framework of little value to Council in guiding future decisions. Developers and NEAA, on the other hand, embraced the strategy for the same reason. In a vote of four-to-one, the five-member executive committee of council approved the strategy (City of Edmonton, 2012a), setting the stage for the struggle over the Area Structure Plan.

\section{Round Two: The battle over the Horse Hill Area Structure Plan}

The draft Area Structure Plan for Horse Hill covers 2,700 hectares of land, of which a portion is held by various government institutions, including a hospital and a Department of Defence installation. The proponents of the plan (the developers) own 1,033 hectares of the 1,500 available for development. Of these, Walton holds about 400 hectares (1,000 acres) (Stolte, 2013). As the map in Figure 2 shows, those wishing to continue farming and own their land have their choice of less than 200 hectares. The bulk of the areas shown in beige would be residential development of over 26,000 units for an anticipated population of just under 70,000. The deep red area indicates a town-center retail complex.

The process also included consultations through the advisory committee and citymandated open houses at which citizens could comment on the draft plan. The last was held in November 2012. Walton and the other plan proponents had been active in advertising through billboards and fliers in the northeast in favor of the plan. The draft Horse Hill Area Structure Plan (City of Edmonton, 2013) reflected the proponents' preference for low-density development, which barely met the city’s minimum requirements (Male, 2013). It provided little indication of any preservation of agricultural land beyond that small portion still owned by food producers, and did little to buffer them from encroaching developments. A proposed provincial ring road, smaller arterial roads, and the proposed division of the area into five smaller neighborhood plans appeared to bisect some of the food-producing farms and market gardens. 
The plan also provided figures on the net positive revenue benefit to the city based on assumptions that critics found to be questionable (Male, 2013).

GEA continued to organize public meetings, speak out in the media, encourage calls and e-mails to councillors, create an online petition, and circulate fast-fact commentaries to challenge the arguments of the developers. Public hearings on the draft Area Structure Plan took place over two days in February 2013 and involved many of the same groups that had spoken on the food strategy. GEA local food activists already knew after meeting with some councillors that they did not have the votes on Council to stop or amend the Area Structure Plan, and that some councillors resented their tactics. In their presentations at the final hearings GEA used a democracy frame focusing on the process and the public's demand that Council "get full information about the true costs and benefits of this current plan and alternative development scenarios" (Male, 2013), reflected in an online petition signed by over 2,100 people, which they presented at the hearings. Farmers spoke passionately that the "black gold in this province is not the fossil fuels, it is the black dirt beneath our feet" (Staples 2013), while developers focused on growth forecasts and the need for more housing. Although a few councillors were sympathetic to the farmers and critical of the process, most voted for the plan-arguing that the cost of preserving the land was prohibitive, that opportunities to create a food hub were more feasible at the regional level, and that issues, such as the ring road, were under the purview of the province. The Area Structure Plan passed easily by ten to three votes, and by the end of April 2013 had received final approval from the Capital Region Board (the twenty-four-member committee of elected officials from municipalities and counties in the Edmonton Region). 


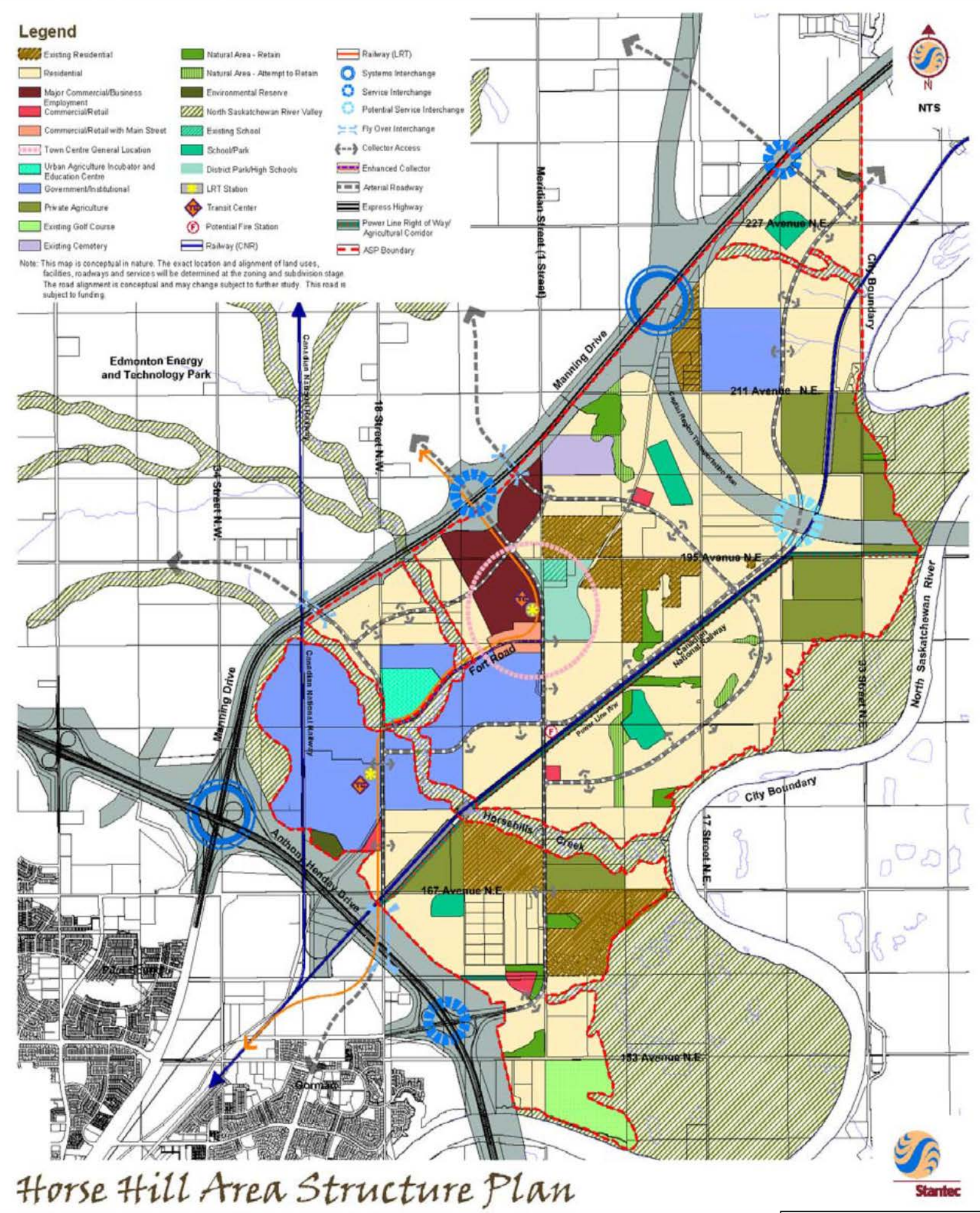

Vi1616stvel116180106drawing SPUSP_HH__15/3n2013 O49

Figure 2: Land use concept, Draft Area Structure Plan (City of Edmonton, 2013) 


\section{Conclusion}

This article has examined one case of building a local food movement and resisting the loss of agricultural land through financialization and speculative investment. One might argue, given the scale of land acquisition and control it affords the purchaser, that this type of investment constitutes a sort of "land grabbing North-American style." The loss of farmland is not unique to Edmonton, however. As Oberholtzer et al. (2010) indicate, the American Farmland Trust estimates that 1.2 million acres in the United States are converted to residential and commercial uses each year. Increased population growth has put urban-edge farming under pressure. While urban growth may provide local farmers with opportunities for gaining access to a large market, there is also some evidence that it creates conflict between farmers and urban dwellers and raises the cost of land (Nickerson et al., 2012), limiting access for new, younger farmers. Clearly urban expansion has raised issues of farmland protection across North America. However, the development of large-scale land acquisitions around urban areas by investment firms, such as the one described above, may limit the effectiveness of land-use tools to preserve farmland and a local food supply. Yet studies indicate that protecting farmland is a public preference (Mathews, 2012), and one that is closely linked to an interest in, and preference for, locally produced food.

In Edmonton, this was reflected in GEA's ability to elevate and politicize the issue of local food and land to grow it on. However, the case indicates that their efforts were clearly not enough. As one GEA local food activist observed:

Ten has turned into thousands. Our relationships, which began at the dinner table, got us to the decision table with enough power to negotiate a good deal for future generations. However, powerful players, mainly interested in short-term financial gain, remain at the table as well (Interview 2013).

The reality is that those powerful players more than remained at the table.

The challenge posed by the transnational process of financial property speculation on agricultural land near urban areas, represented by Walton, merits further research. It raises important questions for local food movements as well. Large pools of investment funds allow for strategic acquisitions of large amounts of land, giving the purchasers significant influence over land-use decisions and raising important questions. Will such large-scale purchases around urban regions across North America drive up the costs of protecting farmland? Second, will it undermine or limit the effectiveness of locally based land management tools designed to preserve farmland?

In the Edmonton case, GEA's earlier experience with local developers on affordable housing led it to believe it could be part of a negotiated deal, using similar tools and incentives. Having asked for the preservation of 600 hectares of land for agriculture, GEA expected a negotiation around the location and number of hectares and various policy tools used in other cities, such as development transfer credits. But global property speculators-using Walton's model of market exit after the planning process has increased land values—-have no reason nor 
incentive to engage in deals to preserve land for growing food, since the tools to do that would be used in later stages of the land development process. Walton's strategy is based on avoiding that riskier stage by selling off and moving on. In the context of this type of investment, which risks an accelerated loss of farmland (because of the scale of land purchases and the control it affords the purchaser), local food activists are faced with a challenge. They must institutionalize processes based on a wider vision of a local food system that would subvert the prevailing property-rights-based planning process.

This individualistic property rights frame resonates widely with decision-makers, and is deeply embedded in many aspects of urban planning. As the largest land owner, Walton had a lead role in developing the plan, and portrayed itself as a developer rather than a speculator. Despite the public engagement process—-which reflected very strong support for preserving agricultural land (Beckie et al., 2013)—Council justified support for the Horse Hill Area Structure Plan by following its existing planning process. The risk from a local food movement perspective, however, is public disillusionment and disengagement.

The experience of other Canadian cities seeking to preserve agricultural land suggests that regional and provincial levels of government need to be engaged. Those provinces that have had some success in preserving land for food production (Ontario, British Columbia, and Québec) have stronger legislation at the provincial level than Alberta, and while prone to exemptions and pressures of developers (Pond, 2009), they provide additional tools. As Mathews (2012) notes, all US states have at least one farmland protection program. Further research and other case studies might shed light on the extent to which such programs can be tools for local food movements seeking to preserve farmland in the face of these large-scale acquisitions by investors.

As this case indicates, the frame of food security and the desire to ensure a resilient and sustainable local food system can engage and mobilize the public. However, this frame needs to gain the attention of, be translated for, and be implemented by governments (Morgan \& Sonnino, 2010). In order to ensure that public support for a sustainable local food system is translated into policy and action at the city level, democratic reforms are necessary to limit the role of developers and speculators. GEA's research in the 2010 electoral campaign indicated that " $46 \%$ of all contributions to City Council campaigns are from the development industry or those affiliated with it. The amount of developer contributions to individual councillors range from as low as 26\% to as high as 62\%" (Janzen, 2012). These figures are in line with other Canadian cities. As political scientist Robert MacDermid (2009) points out, candidates' reliance on development industry funding in municipal elections affects political outcomes, including decisions that result in urban sprawl and the loss of land to grow food.

The Edmonton case indicates that the struggle over local food may have helped build a food movement but was not successful in preserving farmland in the city. Future decisions on the newly created Food Council will be important—including its composition, mandate, and the resources available to it. As well, the Area Structure Plan is only a framework, and detailed plans on the five neighborhoods within it are still to come. Despite the fall 2014 election of a new mayor, who was sympathetic to the local food movement, the city continues to grow by 
annexation. Current plans supported by the mayor include land on the city's southern boundary toward the international airport, which could take more agricultural land out of food production. Despite the province's recognition of the loss of agricultural land through fragmentation and conversion, especially in the Calgary-Edmonton corridor, it has left it to the twenty-four mayors and reeves in the Edmonton Region to address it. They have finally agreed to do so, but recognize it as a "political minefield' (Stolte, 2014). This may provide another opportunity to build on the work done from 2006-13 and shift away from the property rights frame- - but it would be naïve to ignore the power of large pools of capital and extensive land holdings of investors like Walton in the Region.

Edmonton did not have the options of cities such as Toronto, which initiated a food charter, created a food council, developed a food strategy and then used this process to engage in community development to build a local food movement. Edmonton's unconnected food activists were galvanized by the food crisis, concerns about food security and the loss of even more local food production capacity through impending land use decisions. GEA's focus on mobilizing citizens to get to the table may not have been successful in preserving the land in the northeast, but it forged coalitions of concerned and aware citizens. This case indicates that citizens are challenging Council's disregard for the need to ensure a sustainable and resilient local food system. More work will be needed, however, to preserve a local food system for all citizens—-food eaters and producers alike—in the face of global investors speculating on agricultural land.

\section{References}

ABS News. (2013). Indonesian beef plan sparks foreign investment debate. Retrieved from http://farmlandgrab.org/post/view/22548

Alberta Agriculture. (2002). Loss and fragmentation of farmland. Edmonton: Province of Alberta.

Allen, P. (2010). Realizing justice in local food systems. Cambridge Journal of Regions, Economy and Society, 3, 295-308.

Beaulieu, M. S. (2014). Demographic changes in Canadian agriculture. Ottawa: Statistics Canada.

Beckie, M., Hanson L., \& Schrader, D. (2013). Farms or freeways? Citizen engagement and municipal government in Edmonton's food and agriculture strategy development. Journal of Agriculture, Food Systems and Community Development, 4(1), 15-31.

Borras Jr., S. M. and Franco, J.C. (2012). Global land grabbing and trajectories of agrarian change: A preliminary analysis. Journal of Agrarian Change, 12(1), 34-59. 
Borras Jr., S. M., Kay, C., Gómez S., \& Wilkinson, J. (2012). Land grabbing and global capitalist accumulation: Key features in Latin America. Canadian Journal of Development Studies, 33(4), 402-416.

Burch, D., and Lawrence, G. (2013). Financialization in agri-food supply chains: Private equity and the transformation of the retail sector. Agriculture and Human Values, 30(2), 247258.

City of Edmonton. (2011). The way we green: Environmental strategic plan. Retrieved from http://www.edmonton.ca/city_government/documents/TheWayWeGreen-approved.pdf

City of Edmonton. (2012a). Fresh: Edmonton's food and urban agriculture strategy. Retrieved from http://www.edmonton.ca/city_government/documents/FRESH_October_2012.pdf

City of Edmonton. (2012b). Municipal development plan.

City of Edmonton. (2012c). Population on the rise, Press Release, Chief Economist, Feb 9.

City of Edmonton. (2013). Horse Hill Area Structure Plan: Office consolidation. Current Planning Branch, Sustainable Development Department. Retrieved from: http://www.edmonton.ca/city_government/documents/PDF/Horse_Hill_ASP_Consolidati on.pdf

Claeys, P. (2012). The creation of new rights by the food sovereignty movement: The challenge of institutionalizing subversion. Sociology, 46(5), 844-860.

Clapp, J. (2009). Food price volatility and vulnerability in the global south: Considering the global economic context. Third World Quarterly, 30(6), 1183-1196.

DeLind, L. B. (2011). Are local food and the local food movement taking us where we want to go? Or are we hitching our wagons to the wrong stars? Agriculture and Human Values, 28(2), 273-283.

Edmonton Journal. (2012). Editorial: Urban food and agriculture strategy, titled Fresh, is strangely stale. Retrieved from http://blogs.edmontonjournal.com/2012/10/01/urbanfood-and-agriculture-strategy-titled-fresh-is-strangely-stale/

Food and Agricultural Organization. (2012). Food Price ndex. Rome: United Nations.

Greater Edmonton Alliance. (2009). The way we eat: Creating a vibrant and sustainable local food economy. Retrieved from http://greateredmontonalliance.com/wayweeat.pdf

Greater Edmonton Alliance. (2013). About Us. Retrieved from http://greateredmontonalliance.com/?page_id=5 
Guthman, J. (2007). The Polanyian way? Voluntary food labels as neoliberal governance. Antipode, 39(3), 456-478.

Haley, E. (2013). The plunder of Brant County’s Foodland. Alternatives Journal, 39.2. Retrieved from http://www.alternativesjournal.ca/policy-and-politics/web-exclusive-plunder-brantcountys-foodland

HB Lanarc Consultants. (2012). Agricultural inventory and assessment: City of Edmonton city wide food and urban agriculture strategy. Retrieved from https://landusekn.ca/sites/default/files/Ag\%20Inventory\%20and\%20Assessment\%20Pt\% 201.pdf

Lange, E. (2013). A vision of flipping the iceberg of power: The Greater Edmonton Alliance faces big land and big oil. Innovations in North American community development. Antigonish, NS: Coady Institute, St. Francis Xavier University, June.

MacDermid, R. (2009). Funding City Politics, CSJ Foundation.

Magnan, A. (2012). New avenues of farm corporatization in the prairie grains sector: Farm family entrepreneurs and the case of One Earth Farms. Agriculture and Human Values, 29(2): 161-175.

Male, M. (2012). We all have skin in the game. October 25. Retrieved from http://blog.mastermaq.ca/2012/10/25/we-all-have-skin-in-the-game/

Male, M. (2013). Horse Hill ASP: More proof that Edmonton is addicted to sprawl. Retrieved from http://blog.mastermaq.ca/2013/02/23/horse-hill-asp-more-proof-that-edmonton-isaddicted-to-sprawl/

Margulis, M., Mckeon, N., \& Borras Jr., S.M. (2013). Introduction: Land grabbing and global governance: Critical perspectives. Globalizations, 10(1), 1-23.

Margulis, M. \& Porter, T. (2013). Governing the global land grab: Multipolarity, ideas, and complexity in transnational governance. Globalizations, 10(1), 65-86.

Masson, J., \& LeSage, E.E.C. (1994). Alberta's local governments: Politics and democracy. Edmonton: University of Alberta Press.

Mathews, L.G. (2012). From the ground up: Assessing consumer preferences for multifunctional agriculture. Journal of Agriculture, Food Systems and Community Development, 2(2), 5169.

McMichael, P. (2013). Land grabbing as security mercantilism in international relations. Globalizations, 10(1), 47-64. 
Michael, A.M. (2007). Developers eye Brant County. Brantford Expositor. Retrieved from http://www.brantfordexpositor.ca/2007/10/22/developers-eye-brant-county-2

Morgan, K., \& Sonnino, R. (2010). The urban foodscape: World cities and the new food equation. Cambridge Journal of Regions, Economy and Society, 3(2), 209-224.

National Farmers Union (NFU). (2010). Losing our grip: How a corporate farmland buy-up, rising farm debt, and agribusiness financing of inputs threaten family farms and food sovereignty. A Report by Canada’s National Farmers Union. Retrieved from http://nfu.fairtrademedia.com/sites/www.nfu.ca/files/06-07-losing_grip.pdf

Natural Resources Canada. (2013). Additional statistics on energy. Retrieved from http://www.nrcan.gc.ca/publications/statistics-facts/1239.

Nickerson, C., Morehart, M., Kuethe, T., Beckman, J., Ifft, J., \& Williams, R. (2012). Trends in US farmland values and ownership. Economic Information Bulletin 92, Economic Research Service, United States Department of Agriculture. Retrieved from http://www.ers.usda.gov/media/377487/eib92_2_.pdf

Oberholtzer, L., Clancy, K., and Esseks, J.D. (2010). The future of farming on the urban edge: Insights from fifteen U.S. counties about farmland protection and farm viability. Journal of Agriculture, Food Systems and Community Development, 1(2), 59-75.

Pond, D. (2009). Ontario's Greenbelt: Growth management, farmland protection, and regime change in southern Ontario. Canadian Public Policy, 35(4), 413-432.

Sokolow, A., Hammond, S.V., Norton, M., and Schmidt, E.E. (2010). California communities deal with conflict and adjustment at the urban-agricultural edge. California Agriculture, 64(3), 121-128.

Sommerville, M. (2013). Financializing prairie farmland: Farmland investment funds and the restructuring of family farming systems in central Canada. Working paper 38 of the Land Deal Politics Initiative. Retrieved from http://www.plaas.org.za/sites/default/files/publications-pdf/LDPI38Sommerville.pdf

Starr, A. (2010). Local food: A social movement? Critical Studies-Critical Methodologies, 10(6), 479-490.

Staples, D. (2013). A new suburb on Edmonton's northeast farmland makes sense. Edmonton Journal, February, 28.

Stolte, E. (2011). Locals in Horse Hill want food production on planning plate. Edmonton Journal. Retrieved from http://www.edmontonjournal.com/Locals+Horse+Hill+want+food+production+planning +plate/5111249/story.html 
Stolte, E. (2013). Council Oks development in Horse Hill. Edmonton Journal, February 27. Retrieved from http://globalnews.ca/news/399278/council-oks-development-in-horse$\underline{\text { hill/ }}$

Stolte E. (2014). Capital Region Board agrees to debate the issue of agricultural land preservation. Edmonton Journal. Retrieved from http://www.edmontonjournal.com/Capital+Region+Board+agrees+debate+issue+agricult ural+land+preservation/10199952/story.html

Walton International. (2005) The Walton Four Pillars of Strength: Adding value through conceptual planning. Retrieved from http://www.geocities.ws/wundergunder/Walton/Walton_tri.pdf

Walton International. (2014a). About us. Retrieved from http://www.walton.com/en/about_us

Walton International. (2014b). History. Retrieved from http://waltoninternational.eu/en/company/history

Walton International. (2014c). Strategy. Retrieved from http://waltoninternational.eu/en/expertise/strategy 


\section{Appendix - Timeline}

April 2008 Ebenezer United Church Edmonton held a local food dinner.

September 2008 GEA's “Shake the Hand that Feeds You' organized purchases of 300 baskets of food from local farmers

Fall 2008 GEA attempted to engage key decision makers, mayor, chief planner, Walton CEO. First two refused, Walton would not negotiate.

Nov 12, 2008 GEA organized 500 citizens to come to City Hall for the first public hearing on the Municipal Development Plan. Council requested information from the administration on a Food Security Strategy, and mechanisms to protect prime agricultural land.

April-June 2009500 citizens come to hearings on the Municipal Development Plan, and GEA presented The Way We Eat.

Sept 2009 The Great Potato Giveaway. Thousands dig for free potatoes prompting traffic jams in northeast.

February 2010600 citizens see the MDP pass with a key amendment tying the development of agricultural land to the completion of, and compliance with, a Citywide Food and Agriculture Strategy.

Sept 2011 Horse Hill (NE) Area Structure Plan advisory group meets

Oct 2010 Northeast Agricultural Producers (NEAP) organize and join GEA.

Oct 2011 Food Strategy Advisory Group is established. GEA representative participated.

January to February 2012 GEA developed the ask of preserving in perpetuity $600 \mathrm{H}$ of contiguous land in NE Edmonton (1/3 of the land currently being farmed).

Spring 2012 GEA/ NEAP organized house meetings (over 550 people) across city wards on the issue.

August 2012 GEA sponsored bus tours for the public of the Northeast food producing lands.

Sept 62012 GEA sponsored a workshop by the Mytaskis Institute on policy tools to preserve agricultural land.

Oct 12012 Draft Food Strategy released with online public feedback set for Tuesday Oct 8.

Oct 9 and Oct 18, 2012 GEA held two public meetings, inviting councillors and attempting to hold them accountable. Vast majority refused to come claiming they would prefer to hear from citizens on Oct 26. 
Oct 19, 2012 Release of Final Draft of the food strategy. GEA Representative does not sign off, 6 advisory committee members are critical of the final report.

Oct 26 and Nov 2 City Hall Public hearings on the draft strategy before Executive Committee of Council. Strategy passes.

February 25-26, 2013 City Hall Public Hearings on the Horse Hill (Northeast) Area Structure Plan.

February 26 Council gave approval to first and second reading to the plan by a vote of 10-3. April 2013 Area Structure Plan passes final hurdle at the regional level. 